\title{
Toward Political Participation and Capacity: Elections, Voting, and Representation in Early Modern Scotland*
}

\author{
Keith Mark Brown \\ University of Manchester
}

Democratic forms of government have advanced across the world since 1945, a remarkable achievement given the massive challenges faced by democratic states in the twentieth century. Along with democracy has come a greater trust in elections to hold government accountable and to change government rather than merely bestowing a form of legitimacy on the state. Yet one of the recognized problems facing contemporary liberal states and advocates of democratic reforms in states without democratic traditions is how to progress beyond formal procedural elections to genuine participatory elections, thus building meaningful democratic engagement and capacity. The model adopted in many postcolonial states (often arbitrary constructs) of imposing forms of parliamentary democracy has a checkered history, given the failure of representative institutions to retain control over governing parties and the military. Although there are successful examples in the democratizing of West Germany and Japan at the end of World War II, the record of imposed democratic constitutions is problematic. A more recent example in Afghanistan suggests that for democracy to flourish it needs deeper roots than national elections and that security, basic governance, and the rule of law are prerequisites for its survival. ${ }^{1}$ An explanation for the difficulties encountered by those external agents aggressively promoting liberal values has been the absence of the structural conditions in which democracy might thrive, including adequate capacity across a broad range of political and civic institutions and informal associations. ${ }^{2}$ Discussions about the historical roots of democracy focus on concepts such as the emergence of the public space and ideas about the formation of so-

\footnotetext{
* I would like to acknowledge the assistance of my research associates, Siobhan Talbot and Scott Spurlock, and to thank Alan MacDonald, Alastair Mann, and Oliver Richmond for their helpful comments on earlier drafts of this article.

${ }^{1}$ S. Worden, "Afghanistan: An Election Gone Awry," Journal of Democracy 21 (2010): $11-25$.

${ }^{2}$ R. Beissinger, "Promoting Democracy: Is Exporting Revolution a Constructive Strategy?" Dissent 53 (2006): 18-24; A. L. Phillips, "Exporting Democracy: German Political Foundations in Central East Europe," Democratization 6 (1999): 70-98; M. Cowen and L. Laakso, "An Overview of Election Studies in Africa," Journal of Modern African Studies 335 (1997): 717-44; M. Mietzner, "Indonesia's Democratic Stagnation: Antireformist Elites and Resilient Civil Society," Democratization 19 (2012): 209-29.
}

The Journal of Modern History 88 (March 2016): 1-33

(C) 2016 by The University of Chicago. 0022-2801/2016/8801-0001\$10.00

All rights reserved. 
cial capital, each of which has been advanced as an explanation for why some (predominantly Western) cultures have succeeded in inculcating forms of democracy. ${ }^{3}$ The contribution historians can make to this debate is to stress test such theoretical models and to provide empirical evidence for the emergence of democracy, tracing this process in the history of ideas, institutions, and forms of decision making. In the case of social capital, for example, historical analysis of late medieval and early modern Italian states suggests that the evidence for the roots of civil society is less persuasive than was claimed by theoretical argument. ${ }^{4}$

Here caution needs to be exercised in recognizing in early modern representative systems forms of protodemocracy. Examples of local electoral activity can be found in contemporary authoritarian regimes such as the People's Republic of China, where elements of election determine representation, affect the behavior of political elites, and increase trust in political leaders. ${ }^{5}$ We know that in premodern states, autocratic governments sought to defuse political frustration by recognizing the rights of some subjects, or citizens, to a level of freedom of expression, along with processes of electing representatives to articulate their views in a variety of political forums. But in some societies, such as that of early modern France, that process does not appear to have evolved significantly. ${ }^{6}$ By contrast, while it may no longer be as persuasive to follow the Whiggish trail in England back to Magna Carta, there is a viable thesis linking modern British democracy to much earlier political struggles. ${ }^{7}$ Here we encounter the debate on the origins of different European state systems and, in particular, discussion of the contrast between those

${ }^{3}$ J. Habermas, The Structural Transformation of the Public Space: An Inquiry into a Category of Bourgeois Society (Cambridge, 1989); R. D. Putnam, with R. Leonardi and R. Y. Nanetti, Making Democracy Work: Civic Traditions in Modern Italy (Princeton, NJ, 1993).

${ }^{4}$ For a critique of Putnam's location of democratic origins in the communal politics of early modern Italy, see G. Brucker, "Civic Traditions in Premodern Italy," Journal of Interdisciplinary History 29 (1999): 357-77; E. Muir, "The Sources of Civil Society in Italy," Journal of Interdisciplinary History 29 (1999): 379-406; M. Jurdjevic, "Trust in Renaissance Electoral Politics," Journal of Interdisciplinary History 34 (2004): 601-14.

${ }^{5}$ M. Manion, "Democracy, Community, Trust: The Impact of Elections in Rural China," Comparative Political Studies 39 (2006): 301-24; L. Brandt and M. A. Turner, "The Usefulness of Imperfect Elections: The Case of Village Elections in Rural China," Economics and Politics 19 (2007): 453-80.

${ }^{6}$ D. A. Bell, "The Unrepresentable French?" in Realities of Representation, ed. M. Jansson (New York, 2007), 75-92; T. K. Rabb, "Institutions and Ideas: Planting the Roots of Democracy in Early Modern Europe," in The Making and Unmaking of Democracy: Lessons from History and World Politics, ed. T. K. Rabb and E. N. Suleiman (New York, 2003), 41-58.

${ }^{7}$ See, e.g., R. E. E. Harkness, "The Development of Democracy in the English Reformation," Church History 8 (1939): 3-29; R. A. Cosgrove, "Reflections on the Whig Interpretation of History," Journal of Early Modern History 4 (2000): 147-67. The "uniqueness" of England continues to attract interest, however; see E. Kiser and Y. Barzel, "The Origins of Democracy in England," Rationality and Society 3 (1991): 396-422. 
states that appeared to encourage authoritarian government and those, chiefly England, that nurtured a form of civic society in which liberal ideas and democratic practices developed. ${ }^{8}$ The route from English to British and onward across the Atlantic to the foundations of American political culture is one that is traced with scarcely any sideways glance at the other contributors to that story. Are we to conclude that Scotland, as one of the other partners in the making of Britain, played only a very minor role in the formation of Britain's political culture and that it was a passive importer of English traditions?

At one level, therefore, this article is concerned with how early modern Scotland - a small, independent kingdom ruled by a hereditary monarch in which formal sovereignty resided in parliament — deployed forms of election, voting, and representation, with the goal of understanding what implications these practices had for the formation of Scotland's political culture. This is a complex period in which Scotland's king inherited the English crown in 1603 and in which the parliaments of the two kingdoms were united to form Great Britain in 1707. It was also an era marked by constitutional and religious tensions, revolution, and civil war. In addition, the following discussion of a particular early modern political culture can prompt some thoughts about the place of elections, voting, and forms of representation in the emergence of those conditions that allowed more liberal values to emerge and that might permit them to flourish in contemporary states where they are currently absent.

Most European medieval political systems contained elements of election and representation derived from the Roman principle of Quod omnes tangit, ab omnibus tractari et approbari debet (What touches all should be considered and approved by all). Such processes were initiated by a spectrum of motives ranging from the needs of rulers to demonstrate consent for political actions, chiefly the raising of funds, and the desires of communities to defend their interests from predatory rulers. Elected bodies were found in national or regional assemblies, in town councils, and in some aspects of church polity that, in the case of priories, allowed discreet opportunities for women to vote. ${ }^{9}$ While the problematic argument

${ }^{8}$ T. Ertman, "Explaining Variation in Early Modern State Structure: The Cases of England and the German Territorial States," in Rethinking Leviathan: The Eighteenth-Century State in Britain and Germany, ed. J. Brewer and E. Hellmuth (Oxford, 1999), $23-52$.

${ }^{9}$ B. Manin, The Principles of Representative Government (Cambridge, 1997), 86-88; W. P. Blockmans, "A Typology of Representative Institutions in Late Medieval Europe," Journal of Medieval History 4 (1978): 189-215, and "Representation," in The New Cambridge Medieval History, ed. C. Allmand (Cambridge, 1998), 7:29-64; A. Marongiu, Medieval Parliaments: A Comparative Study (London, 1968); T. Bisson, ed., Medieval Representative Institutions: Their Origins and Nature (Hinsdale, IL, 1973); S. E. Finer, The History of Government from the Earliest Times, vol. 2, The Intermediate Ages (Oxford, 2011), 1024-51; T. Reuter, "Assembly Politics in Western Europe from the Eighth Century to the Twelfth," in The Medieval World, ed. P. Lincham and J. L. Nelson (London, 2001), 432-50. For women voters in the church, see L. Mellinger, "The Election of a FifteenthCentury Abbess," Church History 64 (1993): 529-40; K. Lowe, "Elections of Abbesses 
advocating a vigorous form of popular sovereignty in Scotland, symbolized in the totemic 1320 Declaration of Arbroath, has not borne up to forensic scrutiny, ${ }^{10}$ forms of representative politics were found in Scotland in parliament, ${ }^{11}$ the church, ${ }^{12}$ and royal burghs, ${ }^{13}$ and even in the informal counsel offered to kings and lords..$^{14}$ However, throughout early modern Europe the authority of rulers increasingly was deployed as an instrument of absolutist power to bypass, reduce, or eradicate representational political authority. ${ }^{15}$ In Scotland, as in En-

and Notions of Identity in Fifteenth- and Sixteenth-Century Italy, with Special Reference to Venice," Renaissance Quarterly 54 (2001): 389-429.

${ }^{10}$ For the idea that a form of popular sovereignty existed, see G. Simpson, "The Declaration of Arbroath Revitalised," Scottish Historical Review 56 (1977): 11-33; and the more fanciful E. J. Cowan, "Identity, Freedom and the Declaration of Arbroath," in Image and Identity: The Making and Remaking of Scotland through the Ages, ed. D. Broun, R. J. Finlay, and M. Lynch (Edinburgh, 1998), 38-68. For a skeptical interpretation, see A. A. M. Duncan, The Nation of the Scots and the Declaration of Arbroath (London, 1970); and R. J. Tanner, "Cowing the Community? Coercion and Falsification in Robert Bruce's Parliaments, 1309-1318," in The History of the Scottish Parliament, vol. 1, Parliament and Politics in Scotland, 1235-1560, ed. K. M. Brown and R. J. Tanner (Edinburgh, 2004), 50-73.

${ }^{11}$ R. Rait, The Scottish Parliament before the Union of the Crowns (London, 1901); A. A. M. Duncan, "The Early Parliaments of Scotland," Scottish Historical Review 45 (1966): 36-57; Brown and Tanner, History of the Scottish Parliament, 1; R. J. Tanner, The Late Medieval Scottish Parliament: Politics and the Three Estates, 1424-1488 (East Linton, 2001).

12 J. H. Burns, "The Conciliarist Tradition in Scotland," Scottish Historical Review 42 (1963): 89-104; J. Dowden, "The Appointment of Bishops in Scotland during the Medieval Period," Scottish Historical Review 7 (1909): 1-20, and "The Scottish Crown and the Episcopate in the Medieval Period," Scottish Historical Review 7 (1909): 130-40.

${ }^{13}$ M. Lynch, M. Spearman, and G. Stell, eds., The Scottish Medieval Town (Edinburgh, 1988); T. Keith, "Municipal Elections in the Royal Burghs of Scotland," pt. 1, "Prior to the Union," Scottish Historical Review 13 (1916): 111-25.

${ }^{14}$ J. M. Wormald, Lords and Men in Scotland: Bonds of Manrent, 1442-1603 (Edinburgh, 1985), 28-29, 83-84, 95-96.

${ }^{15}$ Y. Barzel and E. Kiser, "The Development and Decline of Medieval Voting Institutions," Economic Inquiry 35 (1997): 244-60; A. R. Myers, Parliaments and Estates in Europe to 1789 (London, 1975); M. A. R. Graves, The Parliaments of Early Modern Europe (Harlow, 2001). Selective specialist studies include J. R. Major, Representative Government in Early Modern France (New Haven, CT, 1980); J. H. Shennan, The Parlement of Paris (London, 1968; repr., Stroud, 1998); F. L. Carsten, Princes and Parliaments in Germany from the Fifteenth to the Eighteenth Century (Oxford, 1959); H. G. Koenigsberger, "The Parliaments of Piedmont during the Renaissance, 1460-1560," in Estates and Revolutions: Essays in Early Modern European History (New York, 1971), 19-79; J. Mallek, "Estate Assemblies in Norway in the Sixteenth and Seventeenth Centuries," Parliaments, Estates and Representation 21 (2001): 72-90; A. F. Upton, "The Riksdag of 1680 and the Establishment of Royal Absolutism in Sweden," English Historical Review 43 (1987): 281-308; I. A. A. Thompson, "The End of the Cortes of Castile," Parliaments, Estates and Representation 4 (1984): 125-33. The exceptions to this general trend, arguably, were the Venetian Republic, Switzerland, the United Provinces, England, 
gland, that clash between monarchs bolstered by an aggressive divine-right ideology and representative assemblies exposed to new ideas on contractual monarchy brought about a different outcome in which the power of the former was limited. ${ }^{16}$ Importantly, Scotland had its own native institutions and traditions of elections, voting, and representation, and it did not need union with England and exposure to English political ideas and practices to discover them.

A problem arising in any discussion of forms of election is that of language. In June 1617, the Scottish parliament legislated for the election of archbishops and bishops by the dean and chapter of cathedral kirks, determining that this constituency would "choose the person whom his majesty pleased to nominate and recommend to their election." ${ }^{" 17}$ Here is a reminder that early modern ideas about the meaning of election can differ radically from what is commonly understood by that term today, at least within liberal, democratic political cultures. Indeed, comparative typologies of electoral practices, such as affirmation, suggest a wide range of elections appropriate to very different political cultures. ${ }^{18}$ Early modern societies often preferred forms of consensus building to contested elections. ${ }^{19}$ There was suspicion over the use of ballots as opposed to oral voting. ${ }^{20}$ And the lot was viewed as an acceptable alternative to elections, offering a neutral mechanism to overcome mistrust and the formation of factions. ${ }^{21}$ Furthermore, casting a vote was not the only means of participating in governance, and office holding offered another route into understanding how early modern people engaged in forms of citizenship. ${ }^{22}$

and Scotland. For observations on geographic scale and the survival of representative institutions, see D. Stasavage, "When Distance Mattered: Geographic Scale and the Development of European Representative Assemblies," American Political Science Review 104 (2010): 625-43.

${ }^{16}$ J. H. Burns, The True Law of Kingship: Concepts on Monarchy in Early Modern Scotland (Oxford, 1996); R. A. Mason, Kingship and the Commonweal: Political Thought in Renaissance and Reformation Scotland (East Linton, 1998).

${ }^{17}$ K. M. Brown et al., eds., The Records of the Parliaments of Scotland to 1707 (St. Andrews, 2007-12), 1617/5/15, http://www.rps.ac.uk (hereafter RPS).

${ }^{18}$ See, e.g., J. H. Pammett, "A Framework for the Comparative Analysis of Elections across Time and Space," Electoral Studies 7 (1988): 125-42.

${ }^{19}$ See the debate over English elections in D. Hirst, Representatives of the People? Voters and Voting in England under the Early Stuarts (Cambridge, 1975); and M. A. Kishlansky, Parliamentary Selection: Social and Political Choice in Early Modern England (Cambridge, 1986).

${ }^{20}$ H. J. Bernstein, "The Benefits of the Ballot? Elections and Influence in SixteenthCentury Poitiers," French Historical Studies 24 (2001): 621-52.

${ }^{21}$ Manin, Principles of Representative Government, 42-93; Jurdjevic, "Trust in Renaissance Electoral Politics."

${ }^{22}$ M. Goldie, "The Unacknowledged Republic: Officeholding in Early Modern England," in The Politics of the Excluded, c. 1500-1850, ed. T. Harris (Houndsmills, 2001), 153-94. 
Until relatively recently, early modern Scotland was portrayed by historians as a country of despotic kings, overbearing nobles, intolerant clerics, weak institutions, and a subservient people. Today such a polis would be described as a failed state. In that old Whig interpretation, parliamentary union with England in 1707 opened up a road to a more enlightened political culture, even if eighteenthcentury Scotland continued to be seen as the most backward region of ancien régime Great Britain. ${ }^{23}$ That extreme caricature has been replaced by a more complex picture of power networks in which counsel, debate, mediation, and compromise were the most likely options in determining outcomes. Nevertheless, the extent to which early modern Scotland nurtured social capital and political capacity within the public sphere, creating those deeply rooted conditions within which liberal, democratic values might flourish, remains understated.

PARLiamenT $^{24}$

Representative assemblies, particularly at the national and provincial levels, were undermined, ignored, or abolished by rulers throughout much of early modern Europe. In some measure this was deliberate, since there were times when rulers in, for example, the United Provinces, France, and Poland, were acutely aware of the potential threat popular assemblies posed to their freedom. Yet this process of decay was not so much the product of aggressive absolutism as of a pragmatic bypassing of what could be particularist and uncooperative practices by the members of those assemblies. ${ }^{25}$ While some rulers undermined and circumvented representative assemblies, in general the latter were seen by contemporaries not as oppositional to early modern government but as partners in governance where

${ }^{23}$ D. Stevenson, "Twilight before Night or Darkness before Dawn? Interpreting Seventeenth-Century Scotland," in Why Scottish History Matters, ed. R. Mitchison (Edinburgh, 1991), 37-41; and see C. Kidd, Subverting Scotland's Past: Scottish Whig Historians and the Creation of an Anglo-British Identity, 1689-c.1830 (Cambridge, 1993), $130-44$.

${ }^{24}$ For the most comprehensive discussion of the early modern Scottish parliament, see K. M. Brown and A. J. Mann, "Introduction," in The History of the Scottish Parliament, vol. 2, Parliament and Politics in Scotland, 1567-1707, ed. K. M. Brown and A. J. Mann (Edinburgh, 2005), 1-56.

${ }^{25}$ Graves, Parliaments of Early Modern Europe, 114-58; H. G. Koenigsberger, Monarchies, States Generals and Parliament: The Netherlands in the Fifteenth and Sixteenth Centuries (Cambridge, 2001), 240-321; S. Hanley, "The French Constitution Revised: Representative Assemblies and Resistance Right in the Sixteenth Century," in Society and Institutions in Early Modern France, ed. M. Holt (Athens, 1991), 36-50; K. Baran, "Procedure in Polish-Lithuanian Parliaments from the Sixteenth to the Eighteenth Centuries," Parliaments, Estates and Representation 22 (2002): 57-69; K. Sharpe, "Crown, Parliament and Locality: Government and Communication in Early Stuart England," English Historical Review 101 (1986): 321-50; D. L. Smith, Stuart Parliaments, 16031689 (London, 1999), chap. 7. 
the governor and the governed respected a level of mutual responsibility in the interests of the commonwealth. ${ }^{26}$

In Scotland, much of the political debate of the later sixteenth and seventeenth centuries between monarchs and their critics focused on the locus of sovereign power. Yet while opposing political ideas were debated, in practice parliament's sovereignty was unquestioned, and all rulers understood the need to seek the support and approval of the estates. ${ }^{27}$ Of course, there was an ebbing and flowing of power as monarchs and their servants sought to dominate parliament, controlling its membership and processes, in the face of resistance from actors within the political elite who, in varying degrees, wanted to use parliament to resist particular royal policies. ${ }^{28}$ Against the backdrop of that intermittent political struggle, parliament's membership altered between the Protestant Reformation in 1560 and the parliamentary union of England and Scotland in 1707. The first estate of clergy was drastically culled and eventually disappeared; the second, noble estate divided in 1587 into a hereditary peerage that received individual summons and the untitled barons represented by elected shire commissioners; and the third estate of royal burghs was numerically overshadowed by the growing landed interest. ${ }^{29}$

${ }^{26}$ M. Greengrass, "Politics and Warfare," in The Sixteenth Century, ed. E. Cameron (Oxford, 2006), 77-78; for discussion of categories of relationships, see N. Bulst, "Rulers, Representative Institutions, and Their Members as Power Elites: Rivals or Partners?" in Power Elites and State Building, ed. W. Reinhard (Oxford, 1996), 41-58.

27 J. H. Burns, "Political Ideas and Parliament," in The History of the Scottish Parliament, vol. 3, Parliament in Context, 1235-1707, ed. K. M. Brown and A. R. MacDonald (Edinburgh, 2010), 216-44; J. Goodare, "The Scottish Parliament and Its Early Modern 'Rivals,'” Parliaments, Estates and Representation 24 (2004): 147-70; Brown and Mann, "Introduction."

${ }^{28}$ K. M. Brown, "The Reformation Parliament," in Brown and Tanner, History of the Scottish Parliament, 203-33; A. R. MacDonald, "The Parliament of 1592: A Crisis Averted?" in Brown and Mann, History of the Scottish Parliament, 57-81; V. T. Wells, "Constitutional Conflict after the Union of the Crowns: Contention and Continuity in the Parliaments of 1612 and 1621," ibid., 82-100; J. R. Young, "Charles I and the 1633 Parliament," ibid., 101-37; J. J. Scally, "The Rise and Fall of the Covenanter Parliaments, 1639-51," ibid., 138-62; G. H. MacIntosh, "Arise King John: Commissioner Lauderdale and Parliament in the Restoration Era," ibid., 163-83; A. J. Mann, " “James VII, King of the Articles': Political Management and Parliamentary Failure,” ibid., 184-207; D. J. Patrick, "Unconventional Procedure: Scottish Electoral Politics after the Revolution," ibid., 20844; K. M. Brown, "Party Politics and Parliament: Scotland's Last Election and Its Aftermath, 1702-3," ibid., 245-86.

${ }^{29}$ J. Goodare, "The Estates in the Scottish Parliament, 1286-1707," in The Scots and Parliament, ed. C. Jones (Edinburgh, 1996), 11-32; K. F. McAlister and R. J. Tanner, "The First Estate: Parliament and the Church," in Brown and MacDonald, History of the Scottish Parliament, 48-66; K. M. Brown, "The Second Estate: Parliament and the Nobility," ibid., 79-94; A. R. MacDonald, "The Third Estate: Parliament and the Burghs," ibid., 95-121, and "Ecclesiastical Representation in Parliament in Post-Reformation Scotland: The Two Kingdom Theory in Practice," Journal of Ecclesiastical History 50 (1999): $38-61$. 
Since the first estate was reduced to a rump of crown-appointed bishops and the second estate of nobles was hereditary, election was only an issue for the burgh and shire commissioners. ${ }^{30}$ In theory this meant that parliamentary constituencies were scattered throughout the kingdom, although the royal burghs were concentrated in the south and east of the country, while many of the shires did not send commissioners to parliament for decades. In spite of the political tension between the Stewart monarchy and parliament, therefore, early modern Scotland experienced a growing engagement in parliamentary electoral activity. What did this signify, and how did it alter political culture?

The history of royal burghs electing commissioners to parliament had long medieval antecedents, the earliest recorded election being in 1437, rooted in the corporate traditions of municipal society. The burghs organized themselves in preparation for parliament by attending the convention of royal burghs, a body established over the course of the fifteenth century and unique in Europe, where they discussed issues that affected them and voted to agree on a collective position. ${ }^{31}$ By the mid-sixteenth century, therefore, burghs were experienced in elections. Increasingly, however, oligarchic burgh councils monopolized that process, restricting the franchise to magistrates and councilors and, under pressure from parliament, permitting limited involvement by deacons of crafts. At Edinburgh in the later sixteenth century, legislation decreed that the crafts had the right to present the burgh council with a list of six nominees from whom two might be selected to sit on the council. The merchant-dominated council repeatedly tried to find ways around this provision, seeking to block any representation by the crafts or selecting men who were not on the short list. ${ }^{32}$ Occasionally, and usually when rival elite factions were competing, greater popular involvement in elections took place, as at Aberdeen in the 1590s when "the hail toun"- probably the entire burgess body - participated in electing commissioners to parliament or in 1689 when the revolutionary Presbyterian party widened the franchise to defeat royalist candidates. Unfortunately, little is known about these elections, or about what the men taking part in them believed they were doing. What can be ascertained is that increasingly in the seventeenth century, burgh elections were competitive and partisan. ${ }^{33}$ Yet under the revolutionary Covenanting government of the 1640 s, when the royal burghs played a prominent role in parliament and in the govern-

\footnotetext{
${ }^{30}$ On the backgrounds of these elected members, see M. D. Young, The Parliaments of Scotland: Burgh and Shire Commissioners, 2 vols. (Edinburgh, 1992-93).

${ }^{31}$ T. Pagan, The Convention of the Royal Burghs of Scotland (Glasgow, 1926).

32 J. D. Marwick, Edinburgh Guilds and Crafts (Edinburgh, 1909), 92-96, 99, 126.

${ }^{33}$ A. R. MacDonald, The Burghs and Parliament of Scotland, c. 1550-1651 (Aldershot, 2007), 32-34, and "Third Estate," 95-121; M. Lynch, "Introduction," in The Early Modern Town in Scotland, ed. M. Lynch (London, 1987), 13-16; Patrick, "Unconventional Procedure."
} 
ment of the kingdom, enthusiasm for electoral participation was dampened by a reluctance to attend parliament. Commissioners complained about the expense of staying in Edinburgh and the impact such absences had on their businesses, leading to some seeking to avoid election. ${ }^{34}$ Herein lay a mundane but important limitation to the formation of the social capital necessary to the growth of participatory politics.

In later sixteenth-century Scotland, the crown's increasing need for taxation made the cooperation, presence, and assent of the lesser nobility in parliament vital. The introduction of shire elections following legislation at the 1587 parliament was in response to lobbying from this rank of nobles, described variously as barons or lairds, for regular representation. It also met the crown's desire to regulate their unpredictable attendance. These hundreds of untitled tenants-inchief to the crown had a long-standing right to attend parliament, and on especially important occasions significant numbers of them turned up. The most notable example of such an influx occurred in 1560 when around one hundred largely Protestant barons flooded parliament to ensure the overthrow of the Roman Catholic Church. The 1587 act, based on neglected 1428 legislation, introduced a form of annual shire election of parliamentary commissioners by fortyshilling freeholders, a relatively high property qualification. Apart from two small shires that elected one commissioner, each shire elected two commissioners who were then on standby to attend parliament should one be summoned. As with the burghs, each shire had only one vote until 1640 . The take-up of shire seats in parliament might not have been immediate, but the political impact of the shire commissioners was significant, providing the crown with what was by the early seventeenth century a growing problem in managing contested elections and controlling the voting behavior of men at a distance from court patronage. The new electoral system in which commissioners were commonly elected by "pluralitie of voitis," therefore, introduced a regular form of local decision making among a small political elite whose instinct to preserve community cohesion competed with individual and family concerns over status and increasing ideology. ${ }^{35}$ Little is known about how these elections were conducted, but in the seventeenth cen-

\footnotetext{
${ }^{34}$ D. Stevenson, "The Burghs and the Scottish Revolution," in Lynch, Early Modern Town, 182-83.

${ }^{35}$ Brown, "Reformation Parliament," 203-31; Brown and Mann, "Introduction," 19-22; A. MacDonald, "Scottish Shire Elections: Preliminary Findings in Sheriff Court Books," Parliamentary History 34 (2015): 279-94; J. Goodare, "The Admission of Lairds to the Scottish Parliament," English Historical Review 116 (2001): 103-33. Similar developments took place elsewhere in Europe; X. Gil, "Crown and Cortes in Early Modern Aragon: Reassessing Revisionism," Parliaments, Estates and Representation 13 (1993): 109-22, 111; L. Makkai, "The Crown and the Diets of Hungary and Transylvania in the Sixteenth Century," in Crown, Church and Estates: Central European Politics in the Sixteenth and Seventeenth Centuries, ed. R. J. Evans and T. V. Thomas (Basingstoke, 1991), 81-82.
} 
tury, deep ideological divisions and crown interference began to animate local politics. ${ }^{36}$ As was the case in the French Estates General, the English House of Commons, or the Castilian Cortes, these lesser nobles did not exhibit class behavior but operated within geographical and hierarchical patronage networks. ${ }^{37}$

The extent to which there was electoral freedom varied according to the effectiveness of local magnates, or the crown, in enforcing their will. Yet even in periods of heavy-handed crown interference in elections, such as in 1621 and 1633, a significant number of shires and burghs elected commissioners prepared to oppose the crown. One of the criticisms the Covenanters made of Charles I was that he censured commissioners who expressed a "contrarie mynde" and voted against royal policies at the 1633 parliament. ${ }^{38}$ The collapse of Charles I's authority from 1637 led in 1640 to a parliament elected with minimal crown interference, a body that abolished the unelected clerical estate, reduced the influence of officers of state, introduced a Triennial Act to ensure regular sittings of parliament, suspended the powerful committee of the lords of the articles, and doubled the voting power of the shire commissioners. A number of new elected committees evolved, most significantly the committee of estates that governed the kingdom when parliament was not in session. Elections to parliament and voting within it were freed up, although the Covenanters quickly evolved their own means of managing elections and parliamentary business. ${ }^{39}$ During the era of the Restoration monarchy from 1661 to 1688 , the shires and burghs continued to elect men who were normally outside the immediate orbit of court patronage. An indication of the government's concern at the threat posed by free elections came in 1684 when the crown attempted to select commissioners without holding any elections, suggesting that sheriffs and burgh councils be authorized to fill

${ }^{36}$ The source material does not allow the level of debate over these tensions that has occurred in England; see Hirst, Representatives of the People?; Kishlansky, Parliamentary Selection.

${ }^{37}$ J. R. Major, "The Electoral Procedure for the Estates General of France and Its Social Implications, 1483-1651," in The Monarchy, the Estates, and the Aristocracy in Renaissance France (London, 1988), chap. 6; S. L. Adams, "The Dudley Clientele and the House of Commons, 1559-1664," Parliamentary History 8 (1989): 216-89; J. K. Guenfelder, Influence in Early Stuart Elections, 1604-1640 (Columbus, OH, 1981), 213-14, 222-23; I. A. A. Thompson and P. Croft, "Aristocracy and Representative Government in Unicameral and Bicameral Institutions: The Role of the Peers in the Castilian Cortes and the English Parliament, 1529-1664," in Bicameralisme, ed. H. W. Blom, W. P. Blockmans, and H. De Schepper (The Hague, 1992), 63-86; and see Bulst, "Rulers, Representative Institutions, and Their Members," 50-51.

${ }^{38}$ J. Goodare, "The Scottish Parliament of 1621," Historical Journal 38 (1995): 29-51; Wells, "Constitutional Conflict after the Union of the Crowns"; Young, "Charles I and the 1633 Parliament," 130.

${ }^{39}$ J. R. Young, The Scottish Parliament: A Political and Constitutional Analysis (Edinburgh, 1996); Scally, "Rise and Fall of the Covenanter Parliaments." 
vacant seats. ${ }^{40}$ Yet electoral competitiveness was increasing, and parliament intervened in elections whose results were disputed, such as that at the royal burgh of Stirling, where a result was overturned in October 1669 on the grounds that electoral law was not observed (unlike in England, there was never any dispute with the crown over parliament's right to adjudicate over elections). ${ }^{41}$ The revolution of 1688-89 further heightened election activity, as is evident from the growing number of contested elections that were settled by voting in a special parliamentary committee and from the heightened party activity of the 1702 election. ${ }^{42}$ At the same time, parliament was uncomfortable with direct forms of popular engagement such as addresses to the estates. During the union debates in 1706-7, the estates viewed with suspicion the gathering of signatures from men who lay outside the political nation, taking the view that it had sole responsibility "to come to a measured decision without interference."

Although not all members of parliament were elected, all members of parliament participated in forms of electing and voting within parliament. Members were engaged in electing individuals to a variety of political offices or to become members of parliamentary committees. There was a body of opinion, alongside a persuasive level of precedent, that vested the right to determine the royal succession in parliament. That right was exercised when Mary was forced to abdicate in favor of her son, James VI, in 1567; again in 1689 when parliament proclaimed that James VII had forfeited the crown and replaced him with William II and Mary; in 1704 when in the act of security parliament asserted the right to be the arbiter of the royal succession; and in 1707 when Sophia of Hanover was designated heir to Anne. The element of election by parliament was fudged, and in 1567 and 1689 parliament recognized the hereditary successor with the best claim. ${ }^{44}$ Nevertheless, it was parliament that, in practice, chose the monarch. In the related matter of selecting regents for infant kings and queens, late medieval regents were chosen largely on the basis of kinship proximity to the monarch and extraparliamentary political maneuvering. ${ }^{45}$ Yet in 1571 and again in 1572, in the context of civil war, the office of regent was filled by an election. In the former

${ }^{40}$ G. H. MacIntosh, The Scottish Parliament under Charles II, 1660-1685 (Edinburgh, 2007), and "Arise King John"; P. H. Brown et al., eds., Register of the Privy Council of Scotland, 3rd ser., 16 vols. (Edinburgh, 1908-70), 10:35 (hereafter RPC).

${ }^{41} R P S, M 1669 / 10 / 4$ and 1690/4/9, for an example in 1690. For England, D. Hirst, "Elections and the Privileges of the House of Commons in the Early Seventeenth Century: Confrontation or Compromise," Historical Journal 18 (1975): 851-62.

${ }^{42}$ Patrick, "Unconventional Procedure," 208-44; Brown, "Party Politics and Parliament."

${ }^{43}$ K. Bowie, "Public Opinion, Popular Politics and the Union of 1707," Scottish Historical Review 82 (2003): 226-60, 255-56.

${ }^{44}$ RPS, 1567/7/25/1, 1689/3/94, 1704/7/68, 1706/10/257.

45 J. Dawson, Scotland Re-formed, 1488-1587 (Edinburgh, 2007), 93-98; W. K. Emond, "The Minority of King James V, 1513-1528" (PhD diss., University of St. Andrews, 1989), 4. 
case, three candidates were on the short list and the first earl of Mar was elected "by plurality of voices of the said estates."

Parliament's right to a say in the appointment to offices of state and privy councilors was contested with the crown. The estates exercised their right to elect the privy council in 1560 in what was a revolutionary situation with Mary and her husband, Francis II, absent in France, and again in 1578 when, at the commencement of James VI's majority, the privy council was "elected and chosen" by parliament. ${ }^{47}$ While future parliaments did not elect privy council members, until the later 1590s the estates continued to have a formal say in approving names put before it by the crown. Unsurprisingly, the extent of that veto changed with political circumstances. In 1592, parliament restricted a politically weak James VI's freedom to reconstitute privy council membership. Three years later, the English agent at the royal court reported with some satisfaction that "in the election of this new Council I know sundry malcontents, chiefly such as were councilors before and [are] now left out." However, from 1598 a much stronger James VI selected his privy council, even if parliament still used the language of election. ${ }^{48}$

Judges on the court of session, Scotland's highest civil court, were appointed by the crown, but there was some modest resistance to this exercise of prerogative power, and for a brief period during the reign of James VI the court elected new judges from a short list of three provided by the king. The position of the president of the court of session was a particular source of tension with the king, and while in 1587 parliament explicitly detailed the court's right to elect its own president, this proviso was dropped from the ratification of its privileges in future years. Yet even judges appointed by the crown were capable of resisting royal authority. When in 1599 James VI tried to force the court to vote according to his command, the president of the court of session told him that "he would not vote at all nor no honest man there." ${ }^{49}$ Normally the crown got its way, but in 1641 Charles I conceded under pressure that his nominees as officers of state, privy councilors, and court of session judges would be subject to parliamentary approval. Parliament also insisted on the election of its own presiding officer or

${ }^{46} R P S, 1571 / 8 / 2, \mathrm{~A} 1571 / 9 / 3, \mathrm{~A} 1572 / 11 / 2$.

${ }^{47}$ Brown, "Reformation Parliament." Parliament elected a long list of twenty-four names for Francis and Mary to approve; RPS, 1578/7/4.

${ }^{48} R P S, 1587 / 7 / 29$ (but see the different language used a few months earlier; A1578/ 3/11), 1598/12/2; MacDonald, "Parliament of 1592," 72; J. Bain et al., eds., Calendar of State Papers Relating to Scotland and Mary Queen of Scots, 1547-1603, 13 vols. (Edinburgh, 1894-96), 12:75 (hereafter CSP Scotland); J. Goodare, The Government of Scotland, 1560-1625 (Oxford, 2004), 147-48.

${ }^{49} \mathrm{~J}$. Ivory, Forms of Process before the Court of Session, the New Jury Court, and the Commission of Teinds (Edinburgh, 1815-18), 52-53; RPS, 1587/7/30, 1593/4/43, 1594/4/ 32, 1606/6/67; Lord Cooper, Baron of Culross, "The King versus the Court of Session," Juridical Review 58 (1946): 83-92. 
president. $^{50}$ The royal prerogatives were restored in full in 1661, and even after 1689 the king's right to select his ministers and councilors was preserved in the face of ongoing criticism and the emergence of something like an organized opposition within parliament. In practice, especially after 1689 , that choice was reduced by the need to select men who could manage parliament. Thus, the new ministry formed by Queen Anne in 1703 reflected the outcome of the recent parliamentary election. ${ }^{51}$

A culture of electing representatives carried through into the contest for power that took place over the staffing of parliamentary committees. The most important committee was the lords of the articles, which engaged in detailed scrutiny of proposed legislation. Here a system of relatively open elections was progressively replaced in the early seventeenth century by royal nomination, with a consequent impact on the freedom of debate and voting. ${ }^{52}$ During the Covenanting era, the committee structure became more complex, with the country being governed by a series of linked parliamentary committees to which members were competitively elected. ${ }^{53}$ This development was subverted by the crown after the Restoration of the monarchy in 1660, although voting and debate survived in committees and on the floor of the house. ${ }^{54}$ It was only from 1690 that parliament assumed control over appointments to its own committees, determining that their composition would be agreed by each estate electing its own representatives. However, even the reformed parliament fell short of the ambitions of the framers of the revolutionary 1641 constitution, and the crown retained powers that facilitated effective executive management of the assembly. ${ }^{55}$ Over the course of 1689-90, the Club emerged as an organized, if short-lived, political grouping that campaigned for further limitations on royal authority. Its own procedures included the selection of a secretary and of spokesmen on particular issues, although there does

${ }^{50}$ Young, Scottish Parliament, 34-42; RPS, 1641/7/6, 1641/8/55, 1641/8/63, 1641/8/157, 1641/8/162, A1641/8/36, A1641/8/49, M1641/1/1-2.

${ }^{51}$ Brown, "Party Politics and Parliament"; P. Riley, "The Formation of the Scottish Ministry of 1703," Scottish Historical Review 44 (1965): 112-35.

${ }^{52}$ R. J. Tanner, "The Lords of the Articles before 1542: A Reassessment," Scottish Historical Review 89 (2000): 189-212; A. R. MacDonald, "Deliberative Processes in the Scottish Parliament before 1639: Multi-Cameralism and the Lords of the Articles," Scottish Historical Review 81 (2000): 189-212.

${ }^{53}$ Young, Scottish Parliament; A. J. Macinnes, "The Scottish Constitution, 1638-1651: The Rise of Oligarchic Centralism," in The National Covenant in Its British Context, 1638 51, ed. J. Morrill (Edinburgh, 1990), 106-33.

${ }^{54}$ MacIntosh, Scottish Parliament, and "Arise King John”; Mann, "James VII, King of the Articles."

${ }^{55}$ RPS, 1690/4/22; A. J. Mann, "Inglorious Revolution: Administrative Muddle and Constitutional Change in the Scottish Parliament of William and Mary," Parliamentary History 22 (2003): 121-44, and "House Rules: Parliamentary Procedure," in Brown and Mann, History of the Scottish Parliament, 122-56. 


\section{Brown}

not appear to have been any formal election of a leadership. ${ }^{56}$ Effective opposition by the Country Party in deploying its voting strength, especially from 1702, forced the crown to evolve a more sophisticated range of measures, including making tactical concessions, in order to achieve its political objectives. ${ }^{57}$

In the mid-1670s an anonymous pamphleteer claimed that parliament was "the people's representative and its members the choice of the whole nation," a statement that might have been inaccurate while carrying a symbolic truth within it. ${ }^{58}$ By the early eighteenth century, parliament was associated with a long-standing and evolving political culture that valued elections as a legitimate and increasingly necessary means of selecting representatives and reaching agreement. It was by no means a democratic assembly, but with around half of its members chosen by forms of election in burgh and shire constituencies, its committees filled by elections, and decisions in committees and in the chamber being decided by voting, parliament had adopted many of the formal practices that are considered essential in contemporary democratic institutions. Of course, the behavior of its members in pursuing their agendas often undermined the political culture that elections were intended to uphold. It is also worth emphasizing that within parliament there was a powerful body of opinion that at various times advocated a much greater role for elections in the frequency and freedoms of parliaments and in the selection of governments, privy councilors, and judges and even in the choice of rulers.

\section{Courts And Councils}

There is strong contemporary evidence supporting the participation hypothesisnamely, that engagement in one form of civic activity, such as jury service, encourages other forms of political involvement within the community. ${ }^{59}$ That thesis offers a useful route into understanding the significance for Scotland's political culture of other forms of electoral activity and, in particular, teasing out what participation in elections did for the civic awareness of those who took part in such activities.

${ }^{56}$ J. Halliday, "The Club and the Revolution in Scotland, 1689-90," Scottish Historical Review 45 (1966): 143-59.

${ }^{57}$ K. Bowie, "Publicity, Parties and Patronage: Parliamentary Management and the Ratification of the Anglo-Scottish Union," Scottish Historical Review 87 (2008): S78-S93.

${ }^{58}$ C. Jackson and P. Glennie, "Restoration Politics and the Advocates' Secession, 1674-1676," Scottish Historical Review 91 (2012): 96-97.

${ }^{59}$ J. Gentil, E. P. Deess, and P. Weisser, "Civic Awakening in the Jury Room: A Test of the Connection between Jury Deliberation and Political Participation," Journal of Politics 64 (2002): 585-95; J. Gentil, E. Deess, P. Weisser, and J. Meade, "Jury Service and Electoral Participation: A Test of the Participation Hypothesis," Journal of Politics 70 (2008): 351-67. 
One arena in which elections and voting might be expected to be encountered was the law courts. While Scots Law was closer to continental Roman Law than to the Common Law of England, Scotland had its own distinct criminal court system. Although elements of communal representation were present in the assize (burgh councils emerged from assizes, or juries, that previously exercised forms of community government), election was largely absent. The role of the assize was essentially to provide local witnesses. ${ }^{60}$ The selection of juries was not in the hands of the local community, the exception being in the Shetland Isles where the Norse tings continued to enjoy popular engagement until $1615 .{ }^{61}$ In fact, jury service was unpopular, and in March 1597 a convention of the estates legislated to encourage attendance. ${ }^{62}$

Witnesses were summoned by the court until 1672, when parliament transferred authority to the judges. A further refinement in 1690 made the clerk of court responsible, with some oversight by the bench, but over time it was left to the clerks to make up assizes from lists of people liable to be summoned to serve. The connection with the locality was eroded over the same period. ${ }^{63}$ Furthermore, the right of members of an assize to use their vote freely in coming to a verdict was restrained by judges who could instruct juries toward a verdict. Indeed, the lord advocate, the highest officer in the criminal court system, had powers to prosecute jurors on a charge of willful error - assizes of error - if they failed to return the required verdict, although this option was not widely used. ${ }^{64}$ In the mid-1670s, tensions between crown-appointed judges and the advocates erupted over appellate jurisdiction, with the latter trying unsuccessfully to appeal to parliament as a

${ }^{60}$ H. MacQueen, "Regiam Majestate, Scots Law, and National Identity," Scottish Historical Review 74 (1995): 1-25, 2-3, 6; I. Willock, The Origins and Development of the Jury in Scotland, Stair Society 23 (Edinburgh, 1966); P. Duff, "The Scottish Criminal Jury: A Very Peculiar Institution," Law and Contemporary Problems 62 (1999): 173-201. For the assize as witnesses, see, e.g., Robert Pitcairn, Ancient Criminal Trials in Scotland, 3 vols. (Edinburgh, 1833), 3:60.

${ }^{61}$ T. M. Y. Manson, "Shetland in the Sixteenth Century," in The Renaissance and Reformation in Scotland, ed. I. B. Cowan and D. Shaw (Edinburgh, 1983), 200-213.

${ }^{62}$ RPS , 1587/7/64, A1597/3/12.

${ }^{63}$ Willock, Origins and Development of the Jury, 148-58; W. Scott, Trial by Jury: The Manner in Which Common Juries Are Struck and Summoned in Civil Cases, according to the Law of England, Compared with the Manner in Which They Are to Be Struck and Summoned in Scotland, under the New Act of Parliament (Edinburgh, 1815), 18, 20; J. I. Smith, "Criminal Procedure," in Introduction to Scottish Legal History (Edinburgh, 1958), 437-41; RPS, 1672/6/50.

${ }^{64}$ L. Smith, "Sackcloth for the Sinner or Punishment for the Crime? Church and Secular Courts in Cromwellian Scotland," in New Perspectives on the Politics and Culture of Early Modern Scotland, ed. J. Dwyer, R. Mason, and A. Murdoch (Edinburgh, 1982), 127; C. Jackson, " "Assize of Error' and the Independence of the Criminal Jury in Restoration Scotland," Scottish Archives 10 (2004): 1-25. 
more representative and less partial body. ${ }^{65}$ Nevertheless, a point had been made about the lack of independence among the judges. At the time of the 1689 revolution, interference from the bench was listed as a grievance, and the right of judges to prosecute assizes was abolished, but the underlying control from the bench continued. ${ }^{66}$ The court of session, modeled on the Roman curia and dealing with civil justice, did not employ juries, but lesser civil cases that were dealt with in sheriff and private regality courts did make use of assizes for setting prices. ${ }^{67}$

Throughout the sixteenth and seventeenth centuries it is difficult to distinguish local government from the estate administration and jurisdictional authority of the nobility in their barony and regality courts. During the 1640s, central government intruded more into local affairs, and some of this intervention survived into the Restoration. Nevertheless, whoever was exercising power in these communities, there was little room for popular elections: office was either hereditary or - in the case of the commissioners of the peace, newly introduced in 1609appointed ${ }^{68}$ Burghs of barony, or regality, were established under charter by their feudal superior. These usually small and less wealthy towns, or townships, enjoyed a range of rights bestowed by the feudal superior. These rights included electing their magistrates, subject to the approval of their superiors, with a defined qualification for electors. The latter embraced the wealthier members of the community of burgesses and resident proprietors, but the level of property qualification for electors was not high (houses valued at above $£ 10$ Scots). ${ }^{69}$ Unfortunately, there is no evidence of what occurred in such elections or how much real freedom there was under feudal law.

In contrast to rural communities, the government of royal burghs included more robust elements of popular representation. The normally larger and more prosperous royal burghs were distinguished by their charters conferring rights and privileges to engage in international trade, collective activity being coordinated through the convention of royal burghs, which provided a level of oversight and

${ }^{65}$ Jackson and Glennie, "Restoration Politics and the Advocates' Secession," 76-103.

${ }^{66}$ RPS, 1689/3/121, A1689/6/1; H. Cockburn, Observations on the Mode of Choosing Juries in Scotland (Edinburgh, 1822).

${ }^{67}$ A. M. Godfrey, Civil Justice in Renaissance Scotland: The Origins of a Central Court (Leiden, 2009).

${ }^{68}$ K. Brown, Noble Power in Scotland from the Reformation to the Revolution (Edinburgh, 2011), 35-88; M. Sanderson, Scottish Rural Society in the Sixteenth Century (Edinburgh, 1982), 6-20; I. Whyte, Scotland before the Industrial Revolution (London, 1995), 210-11, 216. Arguments for greater emphasis on centralization of decision making can be found in J. Goodare, The Government of Scotland, 1560-1625 (Oxford, 2004), 173-245; Macinnes, "Scottish Constitution, 1638-1651," 90-105.

69 J. Marwick, "The Municipal Institutions of Scotland: A Historical Survey (Concluded)," Scottish Historical Review 1 (1904): 284-86. 
representation in parliament. ${ }^{70}$ Formal popular involvement in burgh affairs was in decline from 1469, when parliament legislated to restrict participation in elections, yet by the sixteenth century there remained enough civic engagement to encourage what could be a robust form of public discourse. ${ }^{71}$ An English observer's impression of burgh politics in 1561 suggests that an unproblematic constitutional system was in operation in which the crown selected the provost of a burgh, while the lesser magistrates, or bailies, were elected by the "commons."72 But other sixteenth-century evidence points to considerable turbulence in burgh politics as merchants and craftsmen clashed and as rival political factions and interests struggled for control. The unstable political condition that characterized Mary's personal reign and the subsequent civil war led to feuding and litigation between rival parties in a number of royal burghs. In October 1567, the privy council was invited to intervene at Cupar in Fife, where the establishment faction argued that any return to election by the "multitude" would lead to a perversion of "the old lovable privileges and custom of the burgh" with "factious men put in the seat of justice." ${ }^{\prime 73}$ Such intense rivalry was to be expected amid religious and political dissension when crown authority was weak, local nobles were vying for control, and burgh factions were particularly bitter. One additional factor in burgh elections after the Reformation was the eligibility of Catholics to hold office, although this requirement was often overlooked, and on September 3, 1574, the privy council had to remind burghs that only the religiously orthodox were permitted to be elected. ${ }^{74}$

Examination of Reformation Edinburgh, a town of about twelve thousand people around 1560, reveals a picture of a relatively tight-knit, self-perpetuating merchant oligarchy, but one in which a quarter of the total merchant community of 357 men listed in 1565 held office at some point in time. Councilors were selected by a process of cross- and self-election that had prevailed since 1469 and was designed to promote continuity. For example, at their annual Michaelmas meeting the old and new councils elected their officeholders - a provost, four bailies, a treasurer, and a dean of guild - from among ten retiring and two new merchant councilors. The retiring officeholders continued to serve as ordinary council

${ }^{70}$ MacDonald, Burghs and Parliament, 57-82; Keith, "Municipal Elections," pt. 1.

${ }^{71}$ Keith, "Municipal Elections," pt. 1:111-14; RPS, 1469/19.

${ }^{72}$ CSP Scotland, 1:555.

${ }^{73}$ M. Verschuur, "Merchant and Craftsmen in Sixteenth-Century Perth," in Lynch, Early Modern Town, 36-54; J. H. Burton et al., eds., RPC, 1st ser., 14 vols. (Edinburgh, 1877-98), 1:582. For other examples, see $R P C$, 1st ser., 1:406 for Jedburgh, 505 for Perth; 2:15, 18 for Inverkeithing, 59 for Ayr, 305, 314 for Forres.

${ }^{74} R P C$, 1st ser., 2:419. There was a further tightening of checks on religious orthodoxy in 1587; M. Graham, The Uses of Reform: "Godly Discipline" and Popular Behaviour in Scotland and Beyond, 1560-1610 (Leiden, 1996), 55-56. 
members. In fact, between 1553 and 1578 the provost was not elected, being imposed by the crown, and was not even a merchant burgess. Two craftsmen were permitted to sit on the council, drawn largely from the six wealthiest and more respectable guilds. ${ }^{75}$

Increasingly, pressure was applied from within burgh elites, by neighboring nobles, and by the crown to discourage popular involvement in elections. In June 1584 , the crown systematically interfered in the election of burgh councils through a special commission. ${ }^{76}$ A similar initiative was launched in 1593 when the crown sought to impose the king's choice of provosts, leading to a standoff with Edinburgh. ${ }^{77}$ Yet while the crown gained an uneasy upper hand over some burghs, local communities resisted interference in their electoral politics. Aberdeen, for example, repeatedly insisted on its right to elect its magistrates, opposing interference from Charles I in the 1630s and from the Covenanter government in the following decade. ${ }^{78}$ Until 1638 at the royal burgh of Montrose in Angus, two councilors retired every year and their replacements were elected by the council, but the burgh magistrates were elected by a broader constituency of burgesses with up to ninety electors taking part. ${ }^{79}$ One means of avoiding having a crown nominee imposed was for burghs to ignore the law insisting that magistrates be elected from within the burgh community and, as occurred at Perth until 1628 , to elect a nobleman as provost. $^{80}$

Later seventeenth-century burgh politics were framed by a lack of confidence within the burgh community, due in large part to financial problems and political caution arising from the disastrous identification with the radical Covenanting agenda of the 1640s and 1650s. Nevertheless, popular discontent continued to surface, often focused on frustration at the restrictions on representation. For example, at Edinburgh in October 1672 a serious riot broke out in connection with a municipal election of a new provost. ${ }^{81}$ Many of the problems of the Restoration period were associated with opposition to the crown's insistence on religious conformity among officeholders, leading in September 1686 to James VII's decision to suspend all elections for magistrates in royal burghs. ${ }^{82}$ Subsequently, the Convention Parliament in 1689 legislated to permit new elections in the royal

${ }^{75}$ M. Lynch, Edinburgh and the Reformation (Edinburgh, 1981), 3-5, 17, 22.

${ }^{76}$ CSP Scotland, 7:4.

77 Ibid., 11:189.

${ }^{78}$ D. Masson and P. H. Brown, eds., RPC, 2nd ser., 8 vols. (Edinburgh, 1899-1908), 6:xxviii-ix, 117, 143-45, 172-74; RPS, 1646/11/54.

${ }^{79}$ Angus Archives, Montrose Burgh Records, Council Minutes M1/1/1 1617-39 (unfoliated). I am grateful to Alan MacDonald for this reference.

${ }^{80} R P C$, 2nd ser., 2:xliii; Brown, Noble Power in Scotland, 118-19.

${ }^{81} R P C$, 3rd ser., 3:605-6; R. A. Houston, Social Change in the Enlightenment: Edinburgh, 1660-1760 (Oxford, 1994), 290-331.

${ }^{82}$ RPC, 3rd ser., 5:xxxii, 326-27; 9:261-62; 11:188; 12:491, 511, 514; 13:173. 
burghs that had suffered "encroatchments on their liberties and preveledges" by the crown, largely through the manipulation of the electorate..$^{83}$

Within the burgh community there were disagreements about who might legitimately engage in political activity, and, on the whole, wealthier merchants maintained control over burgh councils at the expense of craftsmen and other members of the community. Social mobility existed, and the election of lower officers took place in relative freedom, but at the higher level of the burgh magistracy, office holding was reserved for those with wealth and strong social connections within the local community. ${ }^{84}$ Consequently, much of the tension and dynamics around burgh electoral politics was concerned with the representation of occupational groups on the council. In Edinburgh, the dominance of the richer merchants was consolidated by admitting a select number of privileged craftsmen and by preventing lawyers from holding office. The only concessions to allowing outsiders a stake in civic life were at the lower level of kirk session deacons or constables of the burgh court. Yet divisions within the crafts were as important as the rivalry between craftsmen and merchants, so that at Stirling the skinners, hammermen, and baxters used their place on the burgh council to block the progress toward office of other tradesmen. ${ }^{85}$ As for electoral processes, convoluted solutions were negotiated in order to meet the competing demands of stakeholders. At Rutherglen in Lanarkshire, the constitution that had been in force since 1469 was altered in 1671 such that the fifteen council members each named two burgesses who, with the sitting provost and bailies, elected the new provost and two bailies. These new officeholders had to be different from those of the preceding year and had to have served in other burgh offices. The new provost and bailies selected a treasurer and fifteen councilors from a list of thirty submitted by the four deaconries, or crafts, and the remaining burgesses. That list could include men who were members of the retiring council. ${ }^{86}$

Each stage in the Rutherglen process contained elements of selection and election designed to balance different interests, depersonalize the decision-making process, and create distance between the commencement of the process and its final resolution. Craft incorporations had statutory rights with regard to the election

${ }^{83}$ Ancient Laws and Customs of the Burghs of Scotland, vol. 2, 1424-1707 (Edinburgh, 1910), 160-61; Patrick, "Unconventional Procedure."

${ }^{84}$ MacDonald, Burghs and Parliament; L. A. M. Stewart, "Politics and Government in the Scottish Burghs, 1603-1638," in Sixteenth-Century Scotland: Essays in Honour of Michael Lynch, ed. J. Goodare and A. A. MacDonald (Leiden, 2008), 433; H. Dingwall, "The Importance of Social Factors in Determining the Composition of Town Councils in Edinburgh, 1550-1650," Scottish Historical Review 179 (1986): 17-33; Houston, Social Change; R. Sher, "The Dryburgh 'Bustle' of the 1760s," in Dwyer, Mason, and Murdoch, New Perspectives on the Politics and Culture, 180.

${ }^{85}$ Lynch, "Introduction."

${ }^{86}$ D. Murray, Early Burgh Organisation in Scotland (Glasgow, 1924), 2:26-28. 
of their deacons, and here too elections followed an indirect course that balanced the role of officeholders with popular participation. The Glasgow skinners' charter of 1584 required the deacon in office to nominate a "leet," or short list, of four masters from whom a successor would be elected by the members of the craft guild. Crafts established qualifying conditions on who might be elected; it was not uncommon for deacons to be reelected, and anyone who was elected was required to take up office or pay a fine.$^{87}$ However, this process was vulnerable to the merchant lobby in parliament, which sought to restrict and circumvent those rights. ${ }^{88}$ In Edinburgh, the recognized process was for the craft incorporations each to name six persons from whom the burgh council selected three, and it was from these three nominees that the incorporations elected their deacon. Allegations that the merchants undermined the process were made at regular intervals. For example, in 1700 it was claimed that the magistrates manipulated the list, presenting the incorporations with three names, only one of which was eligible ${ }^{89}$ Yet while huge social inequality coexisted within towns, the commitment by political elites to a level of social justice ensured that, although there were instances of tension and occasional flash points, relatively cohesive social relationships were maintained..$^{90}$

Especially within burghs, new social relationships began to form around evolving professions that led to different types of civic engagement outside the formal political structures of burgh government. In Edinburgh, strong professional groupings coalesced around the law, education, and medicine, each with its own organizational dynamic containing elements of selection and election to forms of civic office holding. ${ }^{91}$ Meanwhile, over the course of the seventeenth century, the Faculty of Advocates developed as a professional corporation whose members played an important role in civic society, even engaging in political action. Composed of men of high social status, overwhelmingly drawn from the landed elite, it exercised influence through informal networks. ${ }^{92}$ Elsewhere, active engagement in civic society emerged in new private forums such as Freemason lodges. Between 1599 and 1707, twenty-five Freemasons' lodges were founded, creating

${ }^{87}$ H. Lumsden, History of the Skinners, Furriers and Glovers of Glasgow (Glasgow, 1937), 46-47, 51-52, 54.

${ }^{88}$ For the various acts, see RPS, 1425/3/18, A1552/2/18, A1555/6/27, 1584/5/10, 1593/4/ $57,1594 / 4 / 46$

${ }^{89}$ Some seasonable precautions to all that have any vote or influence in electing the magistrates, town-council, and deacons of the city of Edinburgh (Edinburgh, 1700), 6.

${ }^{90}$ Houston, Social Change, 332-78.

${ }^{91}$ M. H. Dingwall, Late 17th-Century Edinburgh (Aldershot, 1994).

${ }^{92}$ G. Donaldson, "The Legal Profession in Scottish Society in the Sixteenth and Seventeenth Centuries," Juridical Review 21 (1976): 1-19; N. T. Phillipson, "The Social Structure of the Faculty of Advocates in Scotland, 1661-1840," in Law-Making and Law-Makers in British History, ed. A. Harding (London, 1977), 146-56; Jackson and Glennie, "Restoration Politics and the Advocates' Secession." 
voluntary associations that mixed quasi-religious fellowship, professional interests, and sociability. These lodges initially drew their membership from craftsmen but increasingly attracted a wider spectrum of society, including landowners. The prevailing ethos of the lodges was egalitarian, with the officers being elected by the members according to rules first set down in 1598. When in the 1670s nobles began to exercise disproportionate influence at Kilwinning Lodge in Ayrshire, the membership, which had initially welcomed powerful patrons, voted them out of office. ${ }^{93}$ Meanwhile, in towns like Edinburgh and Glasgow, the first coffeehouses opened in 1673 and, as in the rest of Britain, contributed to a growing civic space within which news was quickly communicated, vigorous debate took place, and some political dissent was tolerated..$^{94}$

The law courts, central and local, were dominated by crown-appointed or hereditary judges. The composition and freedom of juries was highly regulated, and there is little evidence of a civic culture emerging from the secular structures of local government. However, within the royal burghs a more vibrant political culture endured in spite of coming under intense pressure from the crown, overbearing noble neighbors, and the determination of wealthy merchant burgesses to exercise oligarchic control. Burgh councils were formed by processes that privileged political insiders and the richest occupational groups, but elections continued to be at the heart of selecting and legitimizing burgh magistrates and councilors, and voting was an important ingredient of conducting council business. Craft incorporations maintained a commitment to elections in the choosing of their officers, and they retained some presence on burgh councils. Meanwhile, by the close of the seventeenth century, other civic bodies were emerging - chiefly in towns - that cultivated the free association of men who adopted forms of election and voting in the selection of their members and officers.

\section{The Church}

Within the medieval Roman Catholic Church, election was recognized as a legitimate means of ascertaining God's will at various levels, from the college of cardinals, who elected the pope, to cathedral and monastic chapters, who elected bishops or abbots. By the late medieval period, many of those electoral processes had been subverted by secular political interests, but there persisted a long tradition of conciliarist thinking that had its advocates in Scotland and that was

${ }^{93}$ D. Stevenson, The Origins of Freemasonry: Scotland's Century, 1590-1710 (Cambridge, 1988), 35, and The First Freemasons: Scotland's Early Lodges and Their Members (Aberdeen, 1988), 69-73; P. Clark, British Clubs and Societies, 1580-1800: The Origins of an Associational World (Oxford, 2000), 311.

${ }^{94}$ S. Pincus, "CCoffee Politician Does Create': Coffeehouses and Restoration Political Culture," Journal of Modern History 67 (1995): 807-34, 813. 
critical of hierarchical, papal power. ${ }^{95}$ In the church polity, the Protestant Reformation in 1560 saw a radical departure from the past, and the First Book of Discipline placed responsibility on "every severall Congragation to elect their Minister," outlining a process of election and confirmation for ministers, elders, and deacons. ${ }^{96}$ There is evidence that, at least in Edinburgh, the form of popular election that evolved in the pre-1560 covert privy kirk survived for a few years. John Knox claimed not only that congregational government prevailed but also that elders were ranked according to whoever attained "the moniest votes," so that "if a poor man exceed the rich man in votes, He precedes him in place," an outcome that was unlikely but possible. There was considerable societal resistance to such shocking, populist ideas that contravened accepted notions of hierarchy. Consequently, the crown, bishops, lay patrons, presbyteries, burgh councils, and congregations competed in the appointment of ministers. By the mid-1570s, congregations were in the process of losing their elective rights, being reduced to granting approval, and kirk sessions filled up with better-off merchants and lawyers. ${ }^{97}$ When the Second Book of Discipline was published in 1578, election was narrowly defined as selection by "the jugement of the eldarschip and consent of the congregatioun." Here a distinction was made between being "callit be God" and "electid be man." 98 Nevertheless, the elective powers of congregations continued to be defended by the Presbyterian wing of the church, the survival of the process of election at the congregational level depending on local circumstances. In Edinburgh, the electorate was restricted to the civic and ecclesiastical authorities, but the process took place in public. On Sunday, October 15, 1620, a meeting was convened in the burgh council house of Edinburgh, in the presence of the burgh council, of the kirk session of Edinburgh with "als manie other citizens as the hous could containe," for the purpose of nominating a list of ministers out of whom two might be chosen. Seven men were nominated, four of whom made it to the short list, and the question of which two ministers should be elected was debated in public for a fortnight. ${ }^{99}$ Of course, the action of casting a vote in these elections was complex, involving a range of motives from discerning God's will to factional politics. The crown's main concern was to ensure that royal supremacy over the church was not challenged, but it was content to allow elections to take place as long as there was no threat

\footnotetext{
${ }^{95}$ Burns, "Conciliarist Tradition," and True Law of Kingship, 47-53; M. Dotterweich, "Conciliar Authority in Reformation Scotland: The Example of the Kennedy/Davidson Debate, 1558-63," in The Church Retrospective, ed. R. N. Swanson, Studies in Church History 33 (Woodbridge, 1998), 289-306.

${ }_{96}$ J. K. Cameron, ed., First Book of Discipline (Edinburgh, 1972), 18-19, 35-37, 96, 99, 125-26, 174-75.

${ }^{97}$ Lynch, Edinburgh and the Reformation, 38-41, 38.

${ }^{98}$ James Kirk, ed., Second Book of Discipline (Edinburgh, 1980), 6-8, 29, 65-67, 89-93, 119-20, 173, 179-80, 184.

${ }^{99} \mathrm{RPC}, 1$ st ser., $12: 368 \mathrm{n}$.
} 
to law and order. Thus, in August 1624, the magistrates of Edinburgh were instructed to oversee "the orderly election of the kirk-sessions by the ministers and magistrates." 100

The Covenanting revolution of the 1640 s restored greater decision making to congregations, but it was not only the crown that disliked populist elections, since lay patrons insisted on exercising their legal rights over those of the congregation. ${ }^{101}$ Yet in 1638 it was local nobles, elected to presbyteries as ruling elders in a first step to being elected as commissioners, who at the revolutionary Glasgow general assembly of November 1638 stiffened the resolve of the more cautious clergy. Throughout the 1640s, lay Covenanting elders played an important role in working with ministers to manage the business of the general assembly, but Covenanting nobles held onto their patronage rights. ${ }^{102}$ It was not until 1649, at the height of radical Covenanting power, that parliament provided for clerically dominated presbyteries to forward suitable names for selection to a kirk session chaired by a minister nominated by the presbytery. ${ }^{103}$ This legislation resulted in local power struggles, such as that at Aberdeen in 1654, when the kirk session protested against the election of John Paterson as minister on the grounds that it had not been consulted. ${ }^{104}$ Indeed, the purging of politically unacceptable ministers was a feature of the period, especially between the 1640s and 1690s. ${ }^{105}$ Lay patronage was restored alongside episcopacy in 1661, creating a groundswell of resistance in southern Scotland in which many people voted with their feet and met in field conventicles. ${ }^{106}$ In 1690, parliament agreed to another variant in which the elders and heritors of a vacant rural parish had the right to propose a candidate to the congregation for approval. ${ }^{107}$

Within the framework of the absolutist state systems that prevailed in France and Spain, the clergy used representative assemblies to influence and moderate government policy, and in some respects the newly formed general assembly of

${ }^{100}$ Ibid., 13:xxiv, 598-99.

101 J. Kirk, Patterns of Reform: Continuity and Change in the Reformation Kirk (Edinburgh, 2012), 368-425.

${ }_{102}$ D. Stevenson, "The General Assembly and the Commission of the Kirk, 16381651," Records of the Scottish Church History Society 19 (1975-77): 59-75.

${ }^{103}$ RPS, $1649 / 1 / 240$.

${ }^{104}$ Selections from the Records of the Kirk Session, Presbytery and Syndod of Aberdeen (Aberdeen, 1846), xliii-xlvi.

${ }^{105}$ D. Stevenson, "Deposition of Ministers in the Church of Scotland under the Covenanters, 1638-51," Church History 44 (1975): 321-35; C. Jackson, Restoration Scotland, 1660-1690 (Woodbridge, 2003), 109; T. Clarke, "Scottish Episcopalians, 1689-1720" (PhD diss., University of Edinburgh, 1987), 578-85; A. Raffe, The Culture of Controversy: Religious Arguments in Scotland, 1660-1714 (Woodbridge, 2012).

${ }^{106}$ E. H. Hyman, "A Church Militant: Scotland, 1661-1690," Sixteenth Century Journal 26 (1995): 49-74; Raffe, Culture of Controversy.

${ }^{107}$ RPS, 1690/4/114. 
the Church of Scotland falls within that taxonomy. ${ }^{108}$ After the Reformation in 1560 , the general assembly struggled to reach an agreed understanding of its role, but in 1576 Chancellor Glamis wrote to Theodore Beza in Geneva that it had become accepted practice to send to the general assembly elders "who are chosen among us yearly from the people and also from the nobility." 109 The involvement of an elected laity in the church courts marked a distinction from the prereformed Roman Catholic Church, and from an early stage clerical and lay commissioners were elected to the general assembly by some presbyteries. ${ }^{110} \mathrm{But}$ this form of congregational government of the church unnerved the crown, which found it difficult to control, and it was unpopular with many aristocratic lay patrons. ${ }^{111}$ Parliament enacted a royal supremacy in 1584 that remained in force for most of this period. However, there was a strong body of Presbyterian opinion that saw the general assembly as deriving its authority from God alone and, consequently, as independent of the crown and of parliament. For long periods, from 1617 to 1639 and from 1654 to 1690 , the crown found it easier to leave the general assembly in abeyance. The Presbyterian aspiration for a full separation of church and state, with the general assembly supreme in the former, was achieved in 1690. ${ }^{112}$ The general assembly of the postrevolution settlement exhibited a commitment to elected representatives, with clerical and lay members being elected annually, the latter being chosen primarily by virtue of their religious beliefs rather than status and wealth. In 1697, the general assembly passed the barrier act that entrenched the rights of the wider church against the manipulation of the general assembly by partisan groupings, insisting that its acts must be approved by a majority of presbyteries, regional bodies of clergy, and lay members elected by congregations or kirk sessions and that they be ratified by the general assembly in the following year. ${ }^{113}$ By the 1690 s, therefore, the general assembly provided an important arena, free from direct crown control, within which elected members voted in an effort to discern the mind of the church.

${ }^{108}$ S. T. Perrone, "Assemblies of the Clergy in Early Modern Europe," Parliaments, Estates and Representation 22 (2002): 45-56, and "The Castilian Assembly of the Clergy in the Sixteenth Century," Parliaments, Estates and Representation 18 (1998): 53-70.

${ }^{109}$ G. Donaldson, "Lord Chancellor Glamis and Theodore Beza," in Scottish Church History, ed. G. Donaldson (Edinburgh, 1985), 120-36, 131.

${ }^{110}$ Graham, Uses of Reform, 2; A. R. MacDonald, The Jacobean Kirk, 1567-1625: Sovereignty, Polity and Liturgy (Aldershot, 1998), 38; D. Shaw, The General Assemblies of the Church of Scotland, 1560-1600: Their Origins and Development (Edinburgh, 1964), 71-72.

${ }^{111}$ Gordon Donaldson, The Scottish Reformation (Cambridge, 1960), 204, 218-23; Kirk, Patterns of Reform, 174-75, 418-25.

${ }^{112}$ Shaw, General Assemblies, 18-20; MacDonald, Jacobean Kirk, and "Ecclesiastical Representation in Parliament."

${ }^{113}$ A. V. Dicey, "Thoughts on the General Assembly of the Church of Scotland under the Constitution of 1690, 1690-1707," Scottish Historical Review 14 (1917): 197-215. This act is still in force today. 
Kirk sessions were the lowest ecclesiastical courts, operating at the congregational level within individual parishes. In the 1550s, the underground privy kirks offered an opportunity for men of modest backgrounds in burghs to take on community leadership roles. After 1560, burgh elites established control over the new kirk sessions, largely pushing the candlemakers, bonnetmakers, journeymen, and apprentices into the background as deacons. Nevertheless, the kirk session offered an alternative route to public office for those excluded from burgh office, such as lawyers in Edinburgh. ${ }^{114}$ The church's new structures created a potential for disrupting the recognized hierarchical norms of society; hence, in 1585, one nobleman expressed concern that the election of lay elders was subversive because "it appeareth that marchandis and craftisme[n] or like rabb[le] in ane station may be called ministeris seing throch the hail realme sic men are electit elders and deaconses." 115 These laymen were elected on an annual basis initially, although this changed to election for life, and the form of the election was usually left to local congregations. ${ }^{116}$ Unfortunately there is little surviving evidence about how these elections were conducted. In some cases, the entire eldership was altered by an election, although a high turnover was more common in burghs. Within towns there was a notable level of overlap between those men elected to kirk elderships and burgh council membership. In the burgh and parish of the Canongate adjacent to Edinburgh, 75 percent of the men elected to kirk eldership between 1632 and 1651 either were or had been serving members of the burgh council. ${ }^{117}$ In rural communities, the absence of a wide choice of fit persons, and the more hierarchical nature of society, commonly led to elders serving for life. At Monifieth in Angus, for example, there were elections of elders in 1573, 1575, and 1579 but no election again for at least twenty years. In these circumstances, power was consolidated in the hands of a few local families who were often in a deferential relationship with the local nobility. ${ }^{118}$

Much of local government, therefore, embracing education, poor relief, and a range of family issues, was determined by these elected individuals. Furthermore, the crown was prepared to sanction their role. In June 1592, parliament made allowance for kirk sessions to deal with beggars when the local sheriff or judges ordinary proved negligent, permitting the minister, elders, and deacons to

${ }^{114}$ M. Lynch, "From Privy Kirk to Burgh Church: An Alternative View of the Process of Protestantism," in Church, Politics and Society: Scotland, 1408-1929, ed. N. MacDougall (Edinburgh, 1983), 85-96.

${ }^{115}$ Cited in Graham, Uses of Reform, 259-60; original source is National Library of Scotland ms Adv. 29.2.8, 128r.

${ }^{116}$ Cameron, First Book, 174-79; Kirk, Second Book, 191-94; J. Cook, Styles of Writs, and Forms of Procedure in the Church Courts of Scotland (Edinburgh, 1850), 8; "Acts: 1694," in Acts of the General Assembly of the Church of Scotland, 1638-1842 (1843), 23545, British History Online, http://www.british-history.ac.uk/report.aspx?compid=60096.

${ }^{117}$ Smith, "Sackcloth for the Sinner or Punishment for the Crime?" 122-23.

${ }^{118}$ Graham, Uses of Reform, 127-28. 
nominate or elect responsible persons to take charge. ${ }^{119}$ Even in the 1650 s the occupying English government operated at a local level in partnership with the elected personnel of kirk sessions. ${ }^{120}$ In the Restoration era, the crown and the bishops extended control over the appointment of elders by making the minister responsible for their selection, leading in some parishes to the government threatening to enforce eldership on men who refused to take up office. But while government sought to weed out dissidents, it did little to alter the underlying dependence on elected elders to administer the business of the kirk session. ${ }^{121}$ After 1690 , elders were elected by the sitting kirk session. ${ }^{122}$

While much of the historiography of a previous age has exaggerated the democratic practices of the Church of Scotland, especially its Presbyterian traditions, there is merit in seeing in its representative structures and culture a respect for elections and voting with broader societal significance. Of course, there were considerable constraints on the freedom of elections. For most of the period from the Reformation in 1560 through to 1690 , the general assembly did not meet; congregational government was restricted by the interests of lay patrons, bishops, and presbyteries; and ministers and parishioners could and did cite God's will in justifying dissent regardless of the process by which a decision was reached. Yet throughout the century and a half that followed the Reformation, large numbers of ordinary people engaged in elections at the parish level that affected broad areas of their lives. Many people also committed to undertake political actions in defense of a form of church government that placed greater emphasis on elections than on the royal prerogative in discerning the mind of God.

\section{The Eighteenth-Century Legacy}

After the parliamentary union of 1707 , Scottish politics were significantly altered. The focus of decision making moved decisively from Edinburgh to a Westminster parliament in London operating under distinct rules in a different political culture. Recognizing this change, John Spottiswoode, an enterprising Edinburgh advocate, identified a market for a confused public. In 1710 he published a guide to Scottish electoral law along with the procedures in use at Westminster and the privileges due to members of the new parliament of Great Britain. ${ }^{123}$ Scotland's representation in that parliament was not ungenerous - at least not in the House of Commons, where the Scots had forty-five seats elected on the existing Scottish

${ }^{119}$ RPS, $1592 / 4 / 91$.

${ }^{120}$ Smith, "Sackcloth for the Sinner or Punishment for the Crime?" 119-20.

${ }^{121}$ W. Foster, Bishop and Presbytery: The Church of Scotland, 1661-1688 (London, 1958), 61-63.

${ }^{122}$ Dicey, "Thoughts on the General Assembly," 197-215.

123 J. Spottiswoode, The law concerning election of members for Scotland (Edinburgh, 1710). 
franchise. The Scottish presence in the House of Lords, however, was small, the large peerage of around 225 hereditary, titled nobles being restricted to sixteen elected representative peers. Here was one narrow but fiercely contested new election in which the prizes for successful candidates were high in terms of access to court patronage. ${ }^{124}$ In the country at large, the momentum of preunion political rivalries continued, and the fiercely contested 1710 general election saw long-standing Scottish party and sectional interests dominating the struggle for political power. ${ }^{125}$ Unfortunately, after 1714 the extension of the intervals between elections to seven years subverted the electoral process, while the oligarchic Whig government concentrated power increasingly in the hands of the dukes of Argyll. Electoral law and procedure remained largely unchanged, resting on long-established feudal law moderated by parliamentary statute, but the absence of the oversight formerly provided by the Scottish parliament allowed the system to become increasingly abused under the more lax Westminster parliament. Consequently, discussion of electoral politics after 1707 has focused on the linked issues of management, patronage, and corruption. ${ }^{126}$

The introduction in 1667 of commissioners of supply to collect the recently enacted "cess" (land tax) was an unlikely beginning for what became a vehicle for eighteenth-century shire communities to develop political participation. Commissioners were drawn from the nontitled landed elite, the property qualifications being low enough to be relatively inclusive. The opportunity to engage in elections emerged after 1690 when parliament specified the need to select a convener, but there are no surviving records of elections until 1738 in Ayrshire. While government retained the right to name the commissions on an annual basis, by the 1740s most men who qualified could expect to be named. By 1731 there were 2,500 commissioners throughout Scotland, a number that rose by almost 58 percent to 3,945 in 1768 . Attendance at meetings was variable, with significant absenteeism, much of the business being handled by an interested minority. However, in 1747 one observer noted that "every man that has land ought to have Some Vote in the laying on the Supply which he is obliged to pay"-in other words, there should be no taxation without representation. In the following decade,

${ }^{124}$ J. Sainty, List of Representative Peers: Scotland, 1707-1962; Ireland, 1800-1961 (London, 1968).

${ }^{125}$ D. Hayton, "Traces of Party Politics in Early Eighteenth-Century Scottish Elections," in Jones, Scots and Parliament, 74-99; D. Szechi, "Some Insights on the Scottish MPs and Peers Returned in the 1710 Election," Scottish Historical Review 40 (1981): 61-75.

${ }^{126}$ J. M. Simpson, "Who Steered the Gravy Train, 1707-1766?" in Scotland in the Age of Improvement, ed. N. T. Phillipson and R. Mitchison (Edinburgh, 1970), 47-72; A. Murdoch, "The People Above": Politics and Administration in Mid-eighteenth Century Scotland (Edinburgh, 1980); J. S. Shaw, The Management of Scottish Society, 17071764: Power, Nobles, Lawyers, Edinburgh Agents and English Influences (Edinburgh, 1983); W. Ferguson, "The Electoral System in the Scottish Counties before 1832," Stair Society Miscellany 2 (1984): 261-94. 
control over the appointment of commissioners was increasingly in the hands of the commissioners themselves, and from the 1760s there were protracted struggles within commissions resulting in contested valuation decisions and elections for offices. ${ }^{127}$

Post-Union burgh politics remained embroiled in oligarchy and corruption. The process of burgh councils electing their successors was entrenched, but appeals to overturn electoral processes were made to the convention of royal burghs, or to the court of session, by rival factions and by craft representatives, indicating some vitality within the political system. Burgh parliamentary elections were contested and could be deeply divisive, even resulting in violence, as at Cupar in 1722. The reduction of burgh parliamentary representation to fifteen indirectly elected seats, however, increased the opportunity to exert influence over the small number of burgh delegates who participated. ${ }^{128}$ Nevertheless, internal burgh politics remained relatively dynamic. Leeting (short-listing) by the craft deacon remained the norm in most crafts, and evidence from the Edinburgh cordinors incorporation indicates a high level of competition and participation in electing deacons to sit on the burgh council. There was also some pressure for reform, and, for example, direct elections were introduced by the Glasgow hammermen in $1760 .{ }^{129}$

The 1707 act of union specifically preserved Scots Law and the Scottish law courts, and appeals to the House of Lords made few inroads into that distinctiveness over the course of the eighteenth century. Here is one area in which English influence might have been beneficial, but the court of session, which presided over important civil cases, continued to refuse to employ juries. ${ }^{130}$ In 1785, an initiative to reduce the number of court of session judges developed into a national debate over the advantages of introducing jury trial to civil cases, a suggestion that was widely criticized on the grounds that it represented unwanted assimilation to English norms. ${ }^{131}$ By the later eighteenth century the role of judges and their officers in selecting juries increasingly was regarded as unjust. ${ }^{132}$

${ }^{127}$ A. Whetstone, Scottish County Government in the Eighteenth and Nineteenth Centuries (Edinburgh, 1981), 61-80, 64.

${ }^{128}$ T. Keith, "Municipal Elections in the Royal Burghs of Scotland," pt. 2, "From the Union to the Passing of the Scottish Burgh Reform Bill in 1833," Scottish Historical Review 51 (1916): 266-78; C. A. Whatley, Scottish Society, 1707-1830: Beyond Jacobitism, Towards Industrialisation (Manchester, 2000), 152.

${ }^{129}$ R. A. Houston, "Popular Politics in the Reign of George II: The Edinburgh Cordinors," Scottish Historical Review 77 (1993): 167-89; Lumsden, History of the Skinners, Furriers and Glovers, 47.

${ }^{130}$ Pressure for reform continued to grow; see, e.g., J. Grahame, Thoughts on Trial by Jury in Civil Causes: With a View to a Reform of the Administration of Justice in Scotland; A Series of Letters (Edinburgh, 1806).

${ }^{131}$ N. T. Phillipson, "Scottish Public Opinion and the Union in the Age of the Association," in Phillipson and Mitchison, Scotland in the Age of Improvement, 125-47.

${ }^{132}$ RPS, 1689/3/121, A1689/6/1; Cockburn, Observations on the Mode of Choosing Juries. 
Other forms of association emerged from their trade guild roots and increasingly involved higher-status groups in society, as well as, occasionally, women. The more prominent such associations included the Edinburgh Philosophical Society, which first appeared in the 1730s; the Select Society of Edinburgh, founded in 1754; and the Edinburgh Speculative Society, founded in 1769. These clubs maintained membership rules that included voting on new members and elections for officers, although the latter took various forms that ranged from open elections to more oligarchic and closed formats. ${ }^{133}$ Even the growing number of book clubs required that officers such as president, treasurer, and secretary be appointed by election from what was often a small membership, thus ensuring a high level of engagement by all members. ${ }^{134}$

One consequence of the 1707 parliamentary union was that in spite of the efforts by the negotiators of the act of union to protect the Church of Scotland from English interference, the restoration of lay patronage by Westminster in 1711 allowed landlords with rights of patronage to appoint ministers. However, the radical edge to Presbyterianism that had played a prominent part in the debates around the union did not disappear. ${ }^{135}$ A prolonged rift within the Church of Scotland over lay patronage resulted in the breaking away of the first formal secession congregations in 1733 , with others following over succeeding decades. ${ }^{136}$ The seceding churches placed great emphasis on the popular election of their ministers. Thus, in January 1737, the Associate Presbytery recorded that ministers and office bearers could only be appointed "by the call and consent of the majority of such in these congregations, who are admitted to the full communion with the church in all her sealing ordinances." ${ }^{.137}$ Even within the Church of Scotland

${ }^{133}$ Clark, British Clubs and Societies, 22-24, 118-21, 195-256. The Library Society at Dalkeith explicitly forbade female membership (201).

${ }^{134}$ D. Allan, A Nation of Readers: The Lending Library in Georgian England (London, 2008), 29, 41; M. R. M. Towsey, Reading the Scottish Enlightenment: Books and Their Readers in Provincial Scotland, 1750-1820 (Leiden, 2010), 56-91, for associational subscription libraries; and see P. Borsay, The English Urban Renaissance: Culture and Society in the Provincial Town, 1660-1770 (Oxford, 1989), 292; D. McElroy, "The Literary Clubs and Societies of Eighteenth Century Scotland: And Their Influence on the Literary Productions of the Period from 1700 to 1800 " (PhD diss., University of Edinburgh, 1952).

${ }^{135}$ J. Stephen, Scottish Presbyterians and the Act of Union, 1707 (Edinburgh, 2007); K. Bowie, "Popular Resistance, Religion and the Union of 1707," in Scotland and the Union, 1707-2007, ed. T. M. Devine (Edinburgh, 2008), 39-53.

${ }^{136}$ R. Sher and A. Murdoch, "Patronage and Party in the Church of Scotland, 17501800," in MacDougall, Church, Politics and Society, 197-220; C. Kidd, "Constructing a Civil Religion: Scots Presbyterian Religion and the Eighteenth-Century British State," in The Scottish Churches and the Union Parliament, 1707-1999, ed. J. Kirk (Edinburgh, 2001), 1-21.

${ }^{137}$ Quoted in J. McKerrow, History of the Secession Church (Glasgow, 1841), 121; and on the elders in the secession congregations, see D. Scott, Annals and Statistics of the Original Secession Church (Edinburgh, 1886), 17-18. 
popular elections survived. When a new minister was to be appointed in Edinburgh, all nine parishes in the city nominated three candidates, these having been agreed on by the individual kirk sessions of ministers and elders as well as the deacons who were usually drawn from lower occupational ranks. ${ }^{138}$ Attempts by government or other bodies to impose their choice of minister could ignite a popular reaction, as occurred in what became known as the Drysdale affair in Edinburgh in 1762: the politically conservative general assembly connived with the burgh council to prevent the election of an evangelical minister, leading to two years of successful agitation. The outcome was not a victory for democratic politics, but it indicated a high level of popular engagement to preserve popular rights to choose ministers. ${ }^{139}$

\section{CONCLUSION}

In contrast to the analysis applied to political ideas, Scottish political institutions and forms of election and representation have received little comment. This lacuna is part of a broader interpretation of early modern Scotland as devoid of robust institutions and in thrall to a toxic blend of corruption and oppression that operated on behalf of an all-powerful aristocracy. In spite of evidence to the contrary, a recurrent historiographic tradition insists that pre-1707 Scotland was a provincial testing ground for Stuart absolutism, while post-1707 Scotland incubated all that was worst about the ancien régime. In this narrative, Scotland's record of popular engagement in forms of civic decision making is useful only in pointing out the worst excesses of the regime that were swept away by the reforming zeal of nineteenth-century Whiggery. According to this view, Scotland's parliament was moribund, a crucial factor in its demise in 1707, its elections to Westminster thereafter being the preserve of a small self-serving elite; the countryside was the plaything of landed nobles; the towns were in the iron grip of merchant oligarchs; the court system was unjust and corrupt; and the church was obsessed with enforcing its version of hypocritical godliness on a poor and culturally deprived people. ${ }^{140}$ That depressing picture has been subject to some revision, however, by historians who argue that while there was an enormously

${ }^{138}$ Sher, "Moderates, Managers and Popular Politics," 181-82.

${ }^{139}$ Ibid.; C. Brown, "Protest in the Pews: Interpreting Presbyterianism and Society in Fracture during the Scottish Economic Revolution," in Conflict and Stability in Scottish Society, 1700-1850, ed. T. M. Devine (Edinburgh, 1990), 83-105. See too S. Brown, "The End of the Old Established Church Ideal in Scotland, 1790-1850," in Kirk, The Scottish Churches and the Union Parliament, 75-102; I. D. Clark, "From Protest to Reaction: The Moderate Regime in the Church of Scotland," in Phillipson and Mitchison, Scotland in the Age of Improvement, 202-3.

${ }^{140}$ B. Lenman, Integration, Enlightenment and Industrialisation: Scotland 1746-1832 (London, 1981), 58. 
unequal distribution of power in society, a wholly top-down understanding of decision making in the eighteenth century offers too crude an insight into the dynamics of power. ${ }^{141}$

Since no alternative is on offer, the fundamental explanation for why British constitutional history finds its roots in England and in English political institutions alone has remained unchallenged. ${ }^{142}$ But what if, alongside its deeply hierarchical structures and undoubtedly corrupt practices, early modern Scotland had a thriving political culture, sustained by strong community engagement and representation? Furthermore, if we accept the theoretical model of a direct relationship between the presence of strong representative agencies within government and local communities, on the one hand, and social and economic development, on the other, then, given Scotland's precocious economic progress in the eighteenth century, we might expect to find levels of political engagement within the public sphere similar to but distinct from those in England. ${ }^{143}$ Scotland lacks the evidence for estimating with any confidence the numbers of people participating in elections, but the arid debate such data have inspired among historians of England suggests this might not be especially helpful. ${ }^{144}$ What the above evidence does indicate is that the seventeenth-century legacy ensured that Scotland had resilient indigenous institutions and a political culture in which recourse to elections was relatively commonplace and that levels of participation in those elections were sufficient to be conducive to nurturing a high road to democracy that was not a consequence of Union. Indeed, a case might be made for union debasing some, although not all, aspects of that native political culture.

The roots of elections and representative assemblies in colonial America have been traced largely to the republican world of classical Greece and Rome and to English antecedents, with some recognition of the role of evangelical religion. Against that general context, an attempt has been made to connect the dots between a populist interpretation of the fourteenth-century Declaration of Arbroath and the more famous eighteenth-century American Declaration of Independence. ${ }^{145}$ That is a step too far, but individual Scots - most famously James Wilson and John Witherspoon - the ideas of the Scottish Enlightenment, and the Scottish Presbyterian contribution to colonial religion are all recognized as playing a role in the formation of the United States. Furthermore, many Scots were found in a wide variety of roles fighting for independence from Great Britain

${ }^{141}$ Whatley, Scottish Society, 1707-1830, 8-9, 150.

${ }^{142}$ Kidd, Subverting Scotland's Past, 130-44.

143 J. Fontana, "Political Representation and Social Progress: An Interpretive Approach," Parliaments, Estates and Representation 24 (2004): 1-11.

${ }^{144}$ Goldie, "Unacknowledged Republic," 157-59.

${ }^{145}$ See $\mathrm{n} .10$ above. 
and establishing the infrastructure of a different kind of polity. ${ }^{146}$ What appears to be missing is a recognition of the importance of Scottish political practices, at the very least to those Scots who found themselves in North America. For a great many of those Scots, the fact that a man could confer legitimacy and indicate his choice by voting for representatives in the church, local government, and parliament was likely to be just as significant as political ideas.

It is clear that, as in contemporary societies, the early modern Scottish case demonstrates that elections are compatible with highly authoritarian political cultures vulnerable to violent outbursts. Nevertheless, the spread of the practice of electing representatives encouraged within Scottish society a willingness to accord legitimacy to those exercising authority, a factor that might account for the peaceful reception of the act of union that created Great Britain in 1707. More detailed work needs to be undertaken on the eighteenth century before we can accept a thesis that parliamentary union with England clogged up some of the outlets for political expression, at least insofar as that expression was manifested in elections, although it does look like this was the case. Herein, perhaps, lies an explanation for the puzzling gap between the recognition of the Scottish Enlightenment's prominence in articulating ideas of civic society and the absence of any appreciation of the political culture that gave birth to those ideas. ${ }^{147}$ It is certainly not possible to say that because a variety of electoral practices existed, Scotland was poised for a form of democracy when it came along. There is no clear route map from the relatively vigorous forms of representative government found in the sixteenth and seventeenth centuries and the emergence of modern forms of democratic politics in the later nineteenth century. Yet Scotland appears to have been better attuned than many European states to the evolution of popular, participatory politics in which elections were deployed to determine the course of events. In this, at least, Scotland was much more like England than like France, while the American colonies were more like Scotland than has perhaps been appreciated. That observation does not underestimate the huge struggle that was required to move Scotland forward from its protodemocratic antecedents, nor does it suggest that there was anything inevitable about the outcome. But the persistent emphasis that generations of men placed on participating in elections in parliament and in local burgh councils, craft guilds, churches, and other forms of associational activity suggests that capacity building may be best constructed from the bottom up alongside engagement in central institutions. Historical

${ }^{146}$ W. Reid, "The Scot in America and the Ulster Scot," Celtic Review 7 (1928): 289317; R. B. Sher and J. R. Smitten, eds., Scotland and America in the Age of the Enlightenment (Edinburgh, 1990). Scots also opposed the American rebels; S. Conway, The British Isles and the War of American Independence (New York, 2000), 132-33.

147 The contrast is observed in J. P. Greene, "Social and Cultural Capital in Colonial British America: A Case Study,” Journal of Interdisciplinary Study 29 (1999): 491-509, 501. 
evidence, therefore, offers some understanding of how the grass roots of democracy might be encouraged over sustained periods, and it is consistent with contemporary studies that emphasize a local focus of political engagement in nurturing democratic ideas and practices in developing states. That prolonged historical process, and the recognition of the value of deep societal and cultural roots, cannot be deployed as an excuse to deny legitimate political rights to those demanding them. However, it might help to explain some of the difficulties in trying to cultivate democracy through elections to national assemblies while neglecting the broader context in which participation in the political process is nurtured. 